\title{
Constitutive Serotonin Transporter Reduction Resembles Maternal Separation with Regard to Stress-Related Gene Expression
}

\author{
Erika Comasco, ${ }^{* \dagger}{ }^{\dagger}$ Dick Schijven, ${ }^{\dagger}$ Hanne de Maeyer, ${ }^{\dagger}$ Maria Vrettou, $^{\dagger}$ Ingrid Nylander, $^{\S}$ \\ Inger Sundström-Poromaa, ${ }^{\ddagger}$ and Jocelien D. A. Olivier ${ }^{*},+, \|$
}

\begin{abstract}
${ }^{\dagger}$ Department of Neuroscience, Science for Life Laboratory, ${ }^{\ddagger}$ Department of Women’s and Children’s Health, and ${ }^{\S}$ Department of Pharmaceutical Biosciences, Uppsala University, 75105 Uppsala, Sweden

"Department Neurobiology, Unit Behavioural Neuroscience, Groningen Institute for Evolutionary Life Sciences, University of Groningen, Groningen 9712 CP, The Netherlands
\end{abstract}

Supporting Information

ABSTRACT: Interactive effects between allelic variants of the serotonin transporter (5HTT) promoter-linked polymorphic region (5-HTTLPR) and stressors on depression symptoms have been documented, as well as questioned, by meta-analyses. Translational models of constitutive 5-htt reduction and experimentally controlled stressors often led to inconsistent behavioral and molecular findings and often did not include females. The present study sought to investigate the effect of 5-htt genotype, maternal separation, and sex on the expression of stress-related candidate genes in the rat hippocampus and frontal cortex. The mRNA expression levels of Avp, Pomc, Crh, Crhbp, Crhr1, Bdnf, Ntrk2, Maoa, Maob, and Comt were assessed in the hippocampus and frontal cortex of 5-htt ${ }^{ \pm}$and 5-htt ${ }^{+/+}$male and female adult rats exposed, or not, to daily maternal separation for $180 \mathrm{~min}$ during the first 2 postnatal weeks. Gene- and brain region-dependent, but sex-independent, interactions between 5-htt genotype and maternal separation were found. Gene expression levels were higher in 5-htt ${ }^{+/+}$rats not exposed to maternal separation compared with the other experimental groups. Maternal separation and $5-h t t^{+/-}$genotype did not yield additive

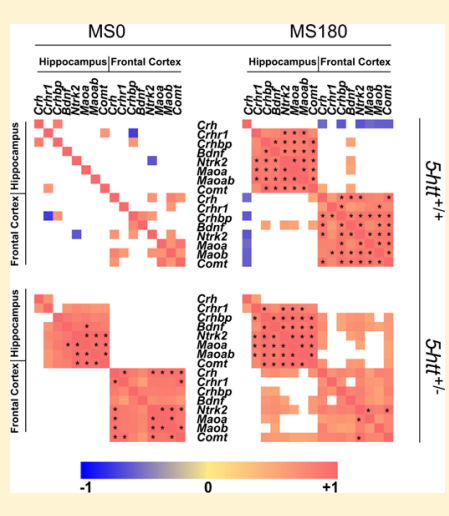
effects on gene expression. Correlative relationships, mainly positive, were observed within, but not across, brain regions in all groups except in non-maternally separated $5-h t t^{+/+}$rats. Gene expression patterns in the hippocampus and frontal cortex of rats exposed to maternal separation resembled the ones observed in rats with reduced 5-htt expression regardless of sex. These results suggest that floor effects of 5-htt reduction and maternal separation might explain inconsistent findings in humans and rodents.

KEYWORDS: Frontal cortex, hippocampus, maternal separation, serotonin transporter, gene expression

\section{INTRODUCTION}

A total of 15 years have passed since Caspi and colleagues provided evidence of an interaction effect of the serotonin transporter linked polymorphic region (5-HTTLPR) with childhood maltreatment on depressive symptoms. ${ }^{1}$ An almostperfectly fan-shaped relationship was presented. In the absence of maltreatment, all three genotypes (i.e., SS, SL, and LL) were associated with a similar probability of depressive episodes, whereas in the presence of maltreatment, the probability was dose-dependently increased by the number of $S$ alleles. ${ }^{1}$ This has been a milestone finding in psychiatric genetics and has prompted not only several replication attempts, as highlighted by reviews and meta-analyses, ${ }^{2,3}$ but also research on the neurobiological mechanisms behind this interaction. ${ }^{4-7}$

Twin studies have indeed demonstrated a moderate degree of heritability for depression, ${ }^{8}$ thus pointing to the importance of studying not only constitutive but also psychosocial factors and their interactive effects. Of particular importance, especially considering the developmental role of serotonin, are those interactions taking place during sensitive periods of an individuaĺs life, such as during fetal development and early life. ${ }^{9,10}$ Because the brain does not reach full maturity until young adulthood, its development is sensitive to factors, such as stress, that can program developmental pathways through epigenetic mechanisms. 9,11 However, we know that not every individual exposed to stress will develop a psychiatric disorder. The genetic makeup, including sex, can set a priori susceptibility as well as moderate environmental influences on mental health. ${ }^{4}$ Regarding sex, compared to men, women are at higher risk for development of depression or receiving treatment for depression. ${ }^{12}$ Selective serotonin reuptake inhibitors (SSRI) is the most common pharmacological treatment modality for depression. SSRIs block the reuptake of serotonin from the synaptic space, thereby leading to increased extracellular levels of serotonin. ${ }^{13}$ Altogether, the 5-

Special Issue: Serotonin Research 2018

Received: November 1, 2018

Accepted: January 7, 2019

Published: January 7, 2019 
HTTLPR has been suggested to influence not only predisposition to depression ${ }^{4}$ but also response to SSRI therapy. ${ }^{14}$

The 5-HTTLPR has been proven to be a functional polymorphism in vitro; ${ }^{15}$ the $\mathrm{S}$ allele has been associated with lower promoter activity and mRNA levels, which ultimately can lead to lower serotonin reuptake. ${ }^{15,16}$ To further understand of the effects of this genotype on the brain, genetically engineered mutations have been created in rodents because they do not have an orthologue of the human polymorphism. ${ }^{4,17,18}$ However, it is important to note that the knockout homozygous rodents $\left(5-h t t^{-/-}\right)$embody a condition that does not exist in humans, thus limiting their translational validity. Conversely, heterozygous rodents $\left(5-h t t^{ \pm}\right)$still display serotonin reuptake but in a reduced manner $(\sim 50 \%$ reduction in 5-HTT availability throughout brain regions), ${ }^{19}$ as in the case of S carriers in humans. ${ }^{15,16}$ Partial and total 5-htt loss-offunction mutations usually are associated with increased serotonin signaling and greater anxiety-like and depressionrelated behavior as well as heightened responses to stress. ${ }^{4,20}$

A pair of brain regions that are reached by serotonergic projections and play a key role in regulating emotions and cognitive functions but also neuroplasticity as well as stress are the hippocampus and frontal cortex. ${ }^{21}$ These regions express receptors for hormones and neurotransmitters released following a stressor. ${ }^{21}$ The stress-response triggers, on the one hand, the activation of the hypothalamic-pituitary-adrenal (HPA) axis with consequent release of corticosteroids (mainly cortisol in humans and corticosterone in rodents) and, on the other hand, the sympathetic systems to release catecholamines (e.g., noradrenaline and adrenaline).$^{22}$ In turn, these hormones and neurotransmitters modulate brain function and behavior by acting on their receptors that are widespread throughout the brain.

To date, reviews and meta-analyses have questioned the interaction between 5-HTTLPR and stress on depressive symptoms, including the underlying mechanisms, ${ }^{2,3,23}$ whereas findings of animal studies have been scattered, and females have often not been included or sex differences have not been investigated. ${ }^{4,20}$ Therefore, the present study sought to investigate the effect of 5-htt genotype, early life stress (triggered by maternal separation), and sex on the expression of candidate genes in the hippocampus and frontal cortex. The expression of HPA axis-related genes (i.e., the arginine vasopressin (Avp), proopiomelanocortin (Pomc), corticotropin-releasing hormone $(\mathrm{Crh})$, corticotropin-binding protein $(\mathrm{Crhbp})$, corticotropin-releasing hormone receptor 1 (Crhrl), neuroplasticity-related genes (i.e., brain derived neurotrophic factor $(B d n f)$, neurotrophic receptor tyrosine kinase 2 $(N$ trk2)), and monoamines metabolism-related genes (i.e., monoamine oxidase a and b (Maoa, Maob) and catechol-Omethyltransferase $(\mathrm{Com} t))$ was assessed in the hippocampus and frontal cortex of male and female rats with normal 5-htt expression $\left(5-h t t^{+/+}\right)$and reduced 5- $h t t$ expression $\left(5-h t t^{ \pm}\right.$) exposed, or not, to daily maternal separation during the first 2 postnatal weeks (Figure 1).

\section{RESULTS AND DISCUSSION}

Results. Gene expression was compared between experimental groups, considering the rearing conditions, genotype, and sex. Crhbp $\left[\chi^{2}(7)=13.5, p=0.01\right], N \operatorname{trk} 2\left[\chi^{2}(7)=15.9\right.$, $p=0.026]$, and Comt $\left[\chi^{2}(7)=15.2, p=0.034\right]$ were differentially expressed in the hippocampus, whereas Ntrk2 $\left[\chi^{2}\right.$

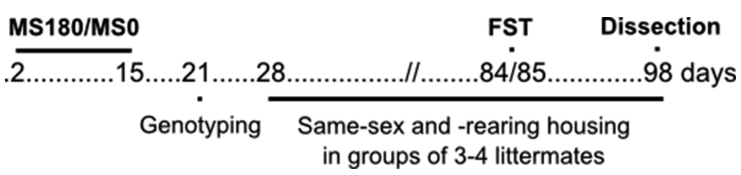

Figure 1. Experimental design. Rats were exposed to daily maternal separation (MS) for $180 \mathrm{~min}$ or no maternal separation (MS0) during the first 2 postnatal weeks. The forced swim test (FST) was assessed during adulthood. Gene expression analyses were performed on hippocampus and frontal cortex tissue dissected on postnatal week 14 .

$(7)=14.3, p=0.046]$ and Comt $\left[\chi^{2}(7)=14.3, p=0.046\right]$ were differentially expressed in the frontal cortex (Figure 2). Nominally significant pair-wise comparisons highlighted differences in the expression of these genes, mainly between $5-h t^{+/+}$ rats not exposed to maternal separation and the other experimental groups (Figure $\mathrm{S} 1$ ).

The 3-way interaction effects between rearing conditions, genotype, and sex were not observed for any gene $(p>0.05)$ in the hippocampus [Crh $(F=0.2 ; p=0.668), \operatorname{Crhr} 1(F=0.9 ; \mathrm{p}$ $=0.342), C r h b p(F=0.1 ; p=0.722), B \operatorname{dnf}(F=1.4 ; p=$ $0.241), \operatorname{Ntrk2}(F=0.4 ; \mathrm{p}=0.531)$, Maoa $(F=0.1 ; p=0.700)$, $\operatorname{Maob}(F=0.4 ; p=0.528)$, and $\operatorname{Comt}(F=1.7 ; p=0.202)]$ and in the frontal cortex $[\mathrm{Crh}(F=0.04 ; p=0.842), \operatorname{Crhr} 1(F=$ $0.1 ; p=0.771), C r h b p(F=0.5 ; p=0.461), B \operatorname{dnf}(F=0.05 ; \mathrm{p}=$ $0.831)$, Ntrk2 $(F<0.001 ; p=0.990)$, Maoa $(F=0.1 ; p=$ $0.782), \operatorname{Maob}(F=0.03 ; p=0.863)$, and Comt $(F=0.1 ; p=$ $0.701)]$. Because of this, males and females were analyzed together and the interaction between rearing conditions and genotype studied. The two-way interactions between rearing conditions and genotype were present (Figure 3): in the hippocampus, for Crhbp $\left(F=7.663, \eta_{p}^{2}=0.133, p=0.008\right.$; adjusted $\left.R^{2}=0.270\right)$ and $N \operatorname{trk} 2\left(F=4.797, \eta_{p}^{2}=0.088, p=\right.$ 0.033 ; adjusted $\left.R^{2}=0.195\right)$; and in the frontal cortex, for Crh $\left(F=4.1, \eta_{p}^{2}=0.077, p=0.048\right.$; adjusted $\left.R^{2}=0.141\right), C r h b p(F$ $=6.743, \eta_{p}^{2}=0.121, p=0.012$; adjusted $\left.R^{2}=0.115\right), B \operatorname{dnf}(F=$ $6.884, \eta_{p}^{2}=0.123, p=0.012$; adjusted $\left.R^{2}=0.137\right), \mathrm{N} t r k 2(F=$ 9.899, $\eta_{p}^{2}=0.168, p=0.003$; adjusted $\left.R^{2}=0.273\right), \operatorname{Maob}(F=$ 7.075, $\eta_{p}^{2}=0.126, p=0.011$; adjusted $\left.R^{2}=0.164\right)$, and Comt $\left(F=9.164, \eta_{p}^{2}=0.158, p=0.004\right.$; adjusted $\left.R^{2}=0.274\right)$. In all cases, the expression of these genes was significantly higher in $5-h t t^{+/+}$rats not exposed to maternal separation compared with the other experimental groups (Figure 3 ).

To facilitate comparisons with previous studies as well as future meta-analyses on the effect of maternal separation on gene expression, complementary analyses were performed. In wild-type rats, maternal separation was associated with lower expression levels of the Crhbp $(U=18, p=0.002)$, Ntrk2 $(U=$ 23, $p=0.004)$, Maoa $(U=36, p=0.031)$, Maob $(U=35, p=$ $0.027)$, Comt $(U=35, p=0.027)$ genes in the hippocampus, as well as of the Crh $(U=40, p=0.024), \operatorname{Crhrl}(U=36, p=$ $0.014), \operatorname{Crhbp}(U=45, p=0.045), B \operatorname{dnf}(U=45, p=0.045)$, Ntrk2 $(U=19, p=0.001)$, Comt $(U=18, p=0.001)$ genes in the frontal cortex (Figure S2). However, the rearing conditions did not influence gene expression in the 5-htt ${ }^{ \pm}$rats.

Regarding animals not exposed to maternal separation, 5-htt \pm compared with 5-htt ${ }^{+/+}$control rats displayed lower expression of the Crhbp $(U=5, p<0.001), B \operatorname{dnf}(U=14, p$ $=0.004), \operatorname{Ntrk} 2(U=10, p=0.002)$, Maoa $(U=9, p=0.001)$, Maob $(U=8, p=0.001)$, Comt $(U=11, p=0.002)$ genes in the hippocampus as well as of the Crh $(U=28, p=0.035)$, Crhr1 $(U=18, p=0.006), C r h b p(U=21, p=0.01), B d n f(U$ $=13, p=0.002), \operatorname{Ntrk2}(U=14, p=0.002)$, Maoa $(U=21, p$ 

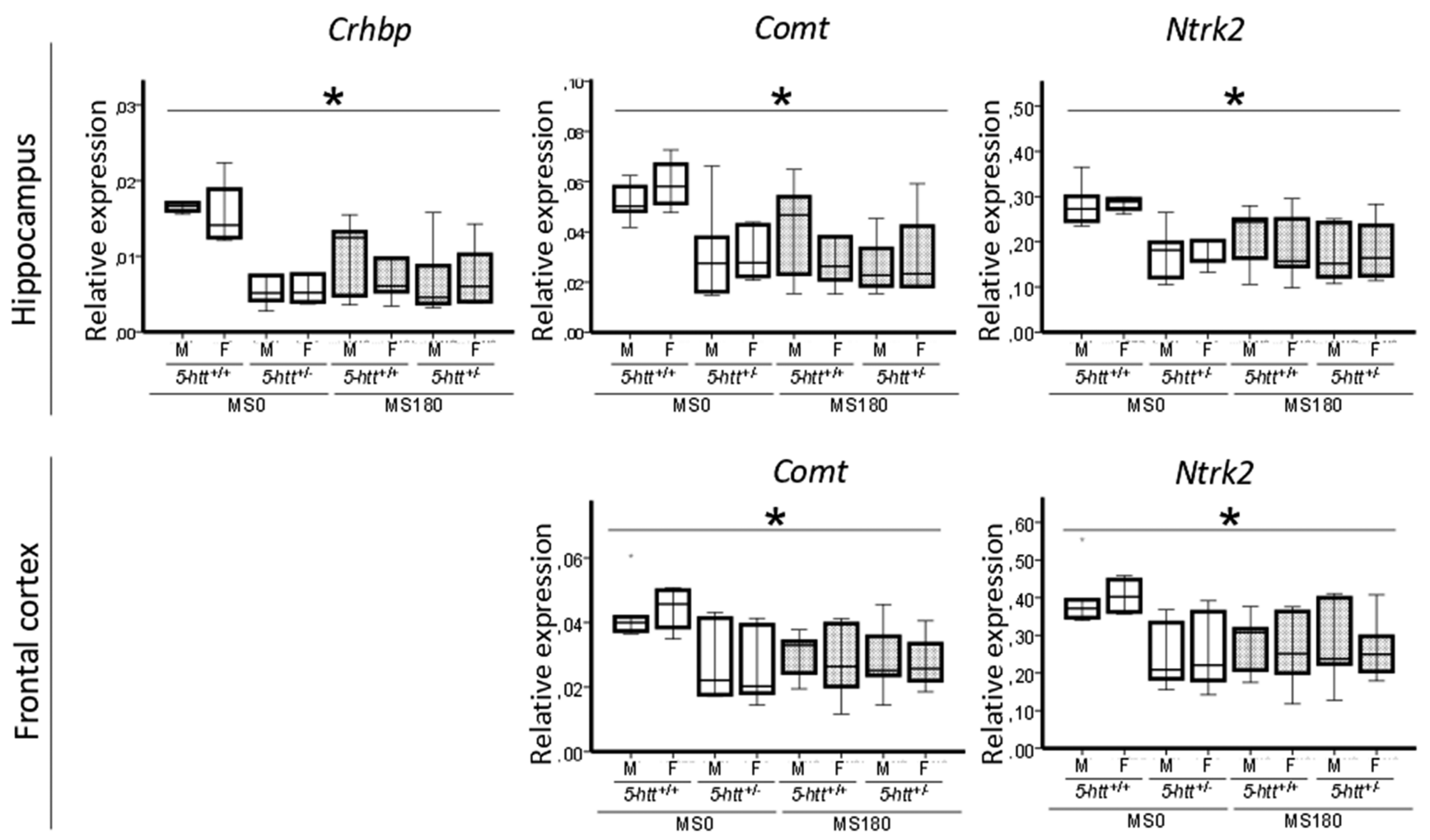

Figure 2. Between-group differences in relative gene expression, considering genotype, rearing conditions, and sex. Pair-wise comparisons are illustrated in Figure S1. F, females; M, males; MS0, no maternal separation; MS180, maternal separation for 180 min; single asterisks, KruskalWallis test result $p<0.05$

$=0.01), \operatorname{Maob}(U=13, p=0.002)$, Comt $(U=20, p=0.008)$ genes in the frontal cortex. Conversely, hippocampal Crh gene expression was higher in 5-htt ${ }^{ \pm}$compared with 5 - htt ${ }^{+/+}$ control rats $(U=25, p=0.035)$ (Figure S3).

When considering rearing and genotype, correlative relationships were observed following Bonferroni adjustment. Positive strong correlations between expression of the genes $(r>0$. 667 ) within, but not across, brain regions were found in all groups except in 5-htt ${ }^{+/+}$controls. Few strong negative correlations were present $(r<-0.829)$ in the $5-h t t^{+/+}$control rats (Figure 4$)$. Sex did not alter these correlative patterns (Figure S4).

Discussion. Both early life stress and constitutive serotonin transporter reduction, independent of sex, were associated with lower expression levels of key genes involved in the stress response system, neuroplasticity and monoamines metabolism. Rats, regardless of sex, exposed to maternal separation or carrying the $5-h t t{ }^{ \pm}$genotype or both displayed lower mRNA levels of Crhbp and Ntrk2 in the hippocampus, as well as lower mRNA levels of Crh, Crhbp, Bdnf, Ntrk2, Maob, and Comt in the frontal cortex compared with the other groups.

To understand the onset of psychiatric disorders, including depression, that are triggered by exposure to stressors and characterized by impaired HPA axis function, we need to advance our knowledge of the neurobiological underpinnings by which the serotonin transporter genotype and early life stress interact to influence brain chemistry. Animal studies enable us to address causality and prospectively investigate the long-term effects of early life stress on health. Indeed, associations with early life stress and maladaptive programming of brain circuits including the regions of interest of the present study have been found as well as reduced top-down inhibition on the amygdala. ${ }^{24,25}$ Previous studies have addressed the role of the serotonin transporter and how this genetic factor interacts with environmental stressors in the hippocampus and frontal cortex (reviewed in Houwing et al.). ${ }^{20}$ Gene- and region-specific differential expression was found in the present study.

In line with our previous findings in the prefrontal cortex (PFC), ${ }^{26} 5-h t t^{ \pm}$rats displayed lower Bdnf mRNA levels in the frontal cortex than $5-h t t^{+/+}$rats not exposed to maternal separation. Similar to other results in the ventromedial PFC, ${ }^{27}$ $5-h t t^{+/+}$rats exposed to maternal separation displayed lower $B d n f$ mRNA levels in the frontal cortex compared with nonseparated rats, and no additive effect of serotonin transporter reduction and maternal separation was observed in $5-h t t^{ \pm}$rats exposed to maternal separation (Figures 3 and S2). BDNF is a neurotrophin playing a role in neuron survival, neurodevelopment, and neuroplasticity whose interaction with serotonin has been demonstrated of relevance to mood disorders by genetic, molecular and pharmacological findings ${ }^{28}$ (e.g., increased BDNF expression following SSRI treatment). ${ }^{29}$ Lower BDNF expression levels in the frontal cortex, as observed here in the presence of serotonin transporter reduction and maternal separation, may indicate impaired ability of the brain to adapt to the environment. ${ }^{30}$ However, contrary to other studies, ${ }^{27,31}$ no differences due to genotype by rearing condition were found in $B d n f$ mRNA levels in the hippocampus, although $5-h t t^{ \pm}$compared with $5-h t t^{+/+}$control rats displayed lower hippocampal Bdnf mRNA levels. Low hippocampal BDNF levels have been associated with psychiatric disorders and with depression-related behavior in animals exposed to environmental stressors. ${ }^{32}$ In the present study, 5-htt \pm genotype and maternal separation were 

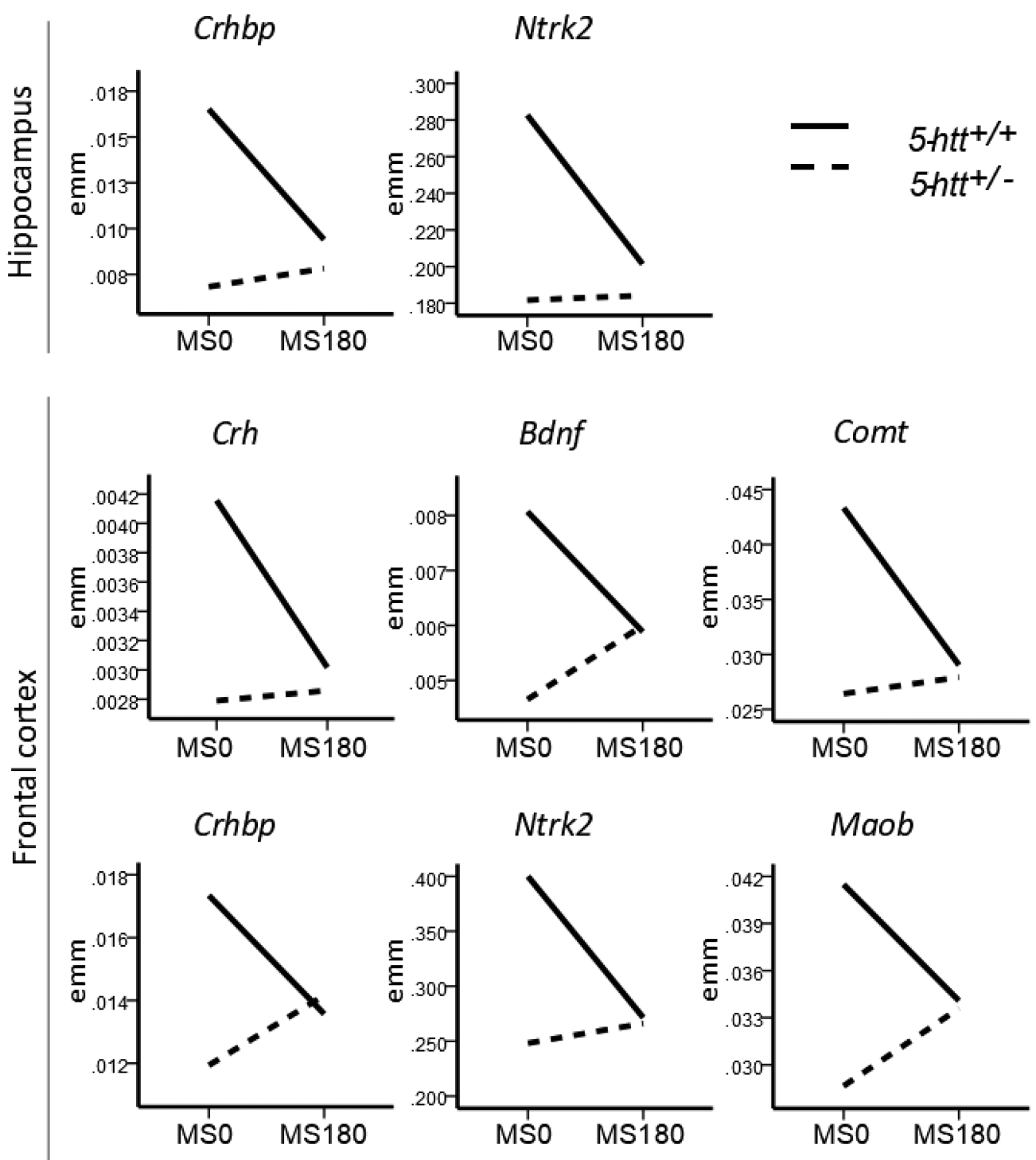

Figure 3. Genotype by rearing condition interaction plots of the estimated marginal means of relative gene expression profiles in the hippocampus and frontal cortex. emm, estimated marginal means; MS0, no maternal separation; MS180, maternal separation for 180 min.

associated with lower mRNA levels of Ntrk2 both in the hippocampus and frontal cortex compared with $5-h t^{+/+}$rats not exposed to maternal separation. Given that NTRK2 is the receptor of BDNF, it is plausible to expect similarity in the expression patterns of Ntrk2 and Bdnf, as observed here (Figures 2, 3, S1, and S2); however, no other study investigated this gene in relation to serotonin transporter reduction and maternal separation previously.

Regarding the HPA axis, Crh mRNA levels in the frontal cortex followed a similar pattern as Bdnf mRNA levels in relation to serotonin transporter genotype and rearing condition (Figures 3 and S2). This is consistent with the lower Crh mRNA levels found in the paraventricular nucleus of the hypothalamus of 5-htt $t^{ \pm}$compared with $5-h t^{+/+}$mice. ${ }^{33}$ However, we found higher basal hippocampal Crh levels in 5$h t t^{ \pm}$rats compared with $5-h t t^{+/+}$rats not exposed to maternal separation, opposite from the effects found in the frontal cortex. Previously no difference in the expression of Crh levels was found in the bed nucleus of the stria terminalis and central amygdala between $5-h t t^{ \pm}$and $5-h t t^{+/+}$rats with or without exposure to early life stress, ${ }^{34}$ thus suggesting that the $5-\mathrm{htt}^{ \pm}$ genotype affects $C r h$ expression levels in a brain region-specific manner. This has previously also been found regarding $B d n f$ expression, where $B d n f$ expression was increased due to stress in the dorsal hippocampus and dorsomedial prefrontal cortex of $5-h t^{ \pm}$rats but decreased due to stress in the ventral hippocampus of 5-htt ${ }^{ \pm}$rats. $^{27}$ Moreover, Bdnf levels were lower in the ventromedial prefrontal cortex of of 5-htt \pm compared with 5-htt ${ }^{+/+}$rats. $^{27}$ The anatomy-dependent expression profile found for $B d n f$, but also the diverse $C r h$ expression across brain areas found in the present study, might pinpoint alterations in mechanisms underlying behavioral outcomes due to reduced 5-htt expression or early life stress that are brain-region-specific. Differences in hormone levels and expression of genes related to the HPA axis have also been identified in previous studies on serotonin transporter reduction and maternal separation, as reviewed by Houwing. ${ }^{20}$ Discrepancies in findings may be explained by compensatory mechanisms taking place downstream in the HPA axis. ${ }^{35}$ Corticolimbic structures also express receptors for $\mathrm{CRH}$, with the hippocampus and frontal cortex exerting inhibitory effects on the HPA axis; ${ }^{35}$ thus, lower Crh mRNA levels in the frontal 


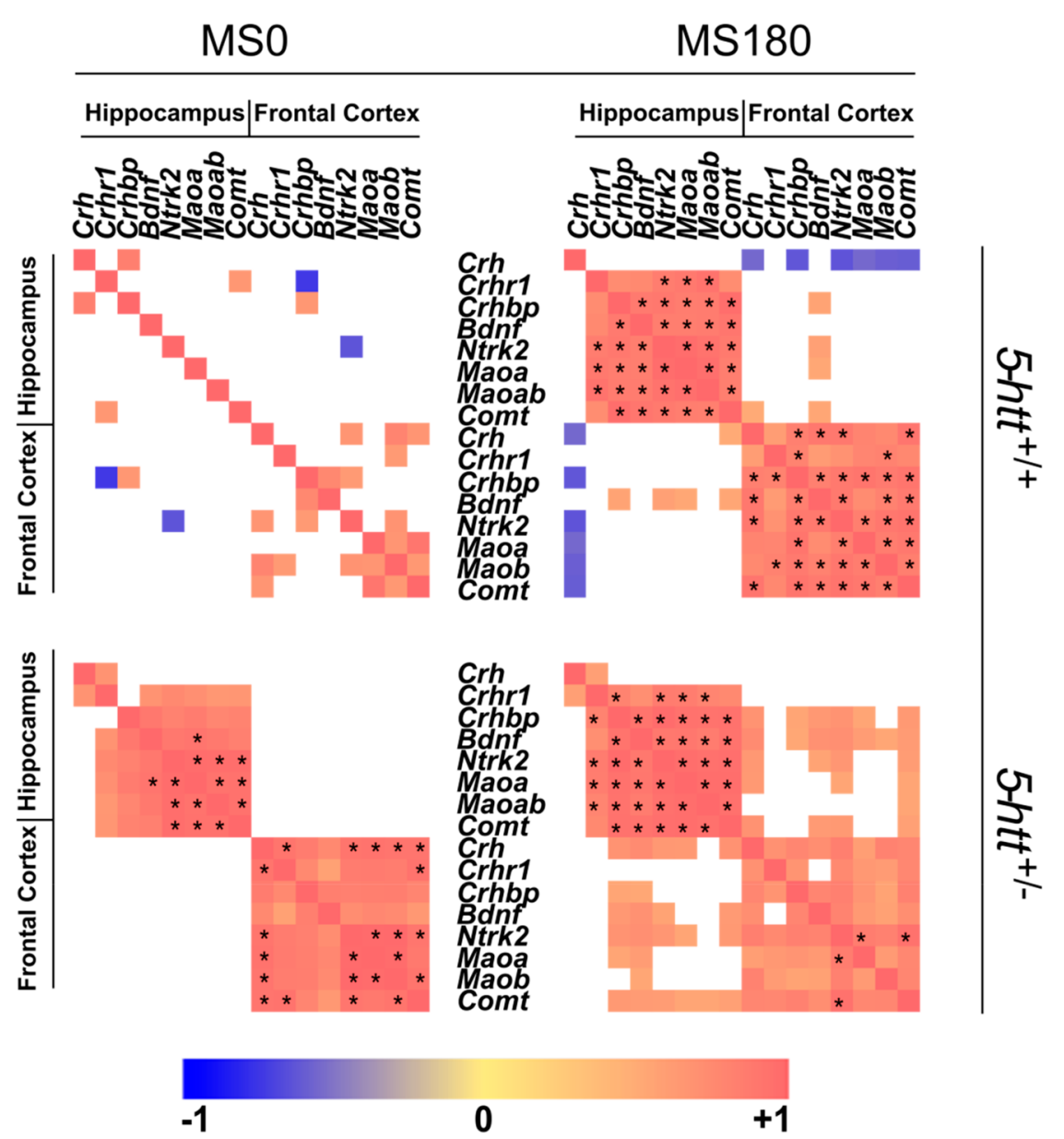

Figure 4. Correlations heat maps of relative gene expression by genotype and rearing condition. The color bar indicates the Spearman's $\rho$; single asterisks indicate significant correlations after correction for multiple testing, and Spearman test results were $p<0.0001$; MS0, no maternal separation; MS180, maternal separation for $180 \mathrm{~min}$.

cortex could lead to hyperactivation of the HPA axis. Maternal separation for $180 \mathrm{~min}$ has indeed been associated with elevated corticosterone levels, ${ }^{36}$ likely resulting from the disruption of the HPA axis negative feedback. By binding to CRHR1, which is expressed in brain regions associated with affective and stress circuitries, ${ }^{37} \mathrm{CRH}$ is known to be involved in phenotypical changes caused by early life stress. Contrary to other studies, we found lower Crhrl mRNA levels in the frontal cortex of nonstressed 5-htt/++ rats compared with maternally separated $5-h t t^{+/+}$and non-stressed 5-htt $t^{ \pm}$rats, following the $\mathrm{Crh}$ expression pattern (Figure S2). Similar to the findings of O'Malley and colleagues, ${ }^{38}$ we found no differences in Crhrl expression in the hippocampus. Interestingly, the study of O'Malley investigated protein levels confirming the present mRNA data. Activation of the $\mathrm{Crh}$ receptors is regulated by the secretory glycoprotein Crhbinding protein (Crhbp), ${ }^{39,40}$ and interestingly, we show that Crhbp mRNA levels resemble the Crh expression levels; they were lower in the presence of maternal separation and 5-htt genotype (Figures 2, 3, S1, and S2).

The stress system is composed of not only the HPA axis but also the sympathetic branch of the autonomic nervous system whose role in the response to stressors takes place through the release of catecholamines, such as norepinephrine and epinephrine. Catecholamines, including dopamine, are metabolized by COMT, which has received attention with regard to its role in stress vulnerability. ${ }^{41}$ The common variant coding a valine (Val, G allele) in the protein sequence of COMT leads to higher COMT activity than the methionine (Met, A allele). ${ }^{42}$ This specific COMT Val158Met polymorphism has been linked to emotional and behavioral disorders, and maternal stress has been shown to increase the risk of childhood behavioral problems in Met/Met carriers of the Val158Met polymorphism. ${ }^{43}$ The present study showed that 5$\mathrm{htt}^{+/+}$rats exposed to maternal separation showed lower Comt expression in the hippocampus as well as frontal cortex (Figure S2), suggesting that Comt expression might be involved in phenotypical changes induced by early life stress. Moreover, compared with $5-h t t^{+/+}$rats, $5-h t t^{ \pm}$rats displayed lower Comt expression in both the frontal cortex and hippocampus (Figures 2, 3, and S1). Regarding the metabolism of monoamines, the gene expression of $M a o b$ in the frontal cortex resembled the gene expression of Comt; a lower gene expression of Maob in male and female rats, both maternally separated as well as with the 5-htt ${ }^{ \pm}$genotype (Figure 3). Interestingly the metabolism of serotonin is also served by monoamine oxidases, even though Maob has a lower affinity to serotonin compared to Maoa. ${ }^{44}$ Maternal separation in 5-htt $t^{+/+}$ rats was associated with lower Maoa and Maob in the hippocampus (Figure S2), whereas the 5- $h t t^{ \pm}$genotype displayed lower gene expression of Maoa and Maob in both the hippocampus and frontal cortex. Disruption of MAOA and MAOB has been implicated in behavioral abnormalities. ${ }^{45}$ Although the basal extracellular levels of 5-HT in the brain are 
not different in 5-htt ${ }^{ \pm}$rats compared with 5-htt ${ }^{+/+}$rats, maternal separation might have challenged the monoaminergic neurotransmission homeostasis underpinning neuropathological changes, especially due to the neurotrophic actions of 5HT. In fact, knowing that the serotonin transporter is responsible for terminating the serotonin signal at the synaptic level through a reuptake mechanism, ${ }^{46}$ any difference in its expression and function can indeed influence serotonin-related physiology, with repercussions for neuroplasticity and emotional and cognitive processing. ${ }^{21}$

Correlative relationships dependent on genotype and rearing condition were observed. The presence of rather strong positive correlations between the expression of stress-related genes within brain regions in rats carrying the $5-h t t^{ \pm}$genotype, exposed to maternal separation, or both suggests a pattern of molecular changes orchestrated by the genetic makeup and environment because this was not observed in 5-htt ${ }^{+/+}$rats unexposed to maternal separation. Interestingly, while lesspositive correlations survived correction for multiple testing in $5-h t t^{ \pm}$rats exposed to maternal separation, the combination of these two factors led to the emergence of positive gene expression correlations also between brain regions. This could be interpreted as an additional $\mathrm{GxE}$ interaction at the brainsystem level; indeed, both the frontal cortex and the hippocampus exert inhibitory control on the HPA axis.

Translational models of constitutive serotonin transporter reduction and experimentally controlled stressors have so far produced inconsistent results, often depending on the behavior or anatomical and molecular substrate analyzed. Moreover, limited designs have undermined several studies, as reviewed by Houwing and colleagues. ${ }^{20}$ The findings of the present study should also be considered in light of its methodological strengths and limitations. While differences in sample size, study design, definition of environmental and phenotypic variables, and statistics have hampered interpretation and generalizability of the results of human studies, ${ }^{4,23}$ animal models as the current one present several advantages. The genetic makeup can be experimentally manipulated and controlled, likewise, the rearing environment; however, this limits the influence of potential confounding factors that are present throughout life and influence phenotypic outcomes. $^{4,47,48}$

In the present study, we employed the $5-\mathrm{htt}^{ \pm}$rats as a translational model for the human s-allele carriers to study the underlying molecular mechanisms involved in early life stress by 5-htt interactions. Though expression of 5-htt was not measured in the present study, 5-htt $t^{ \pm}$rats have been shown to display a $\sim 50 \%$ reduction in 5-HTT availability throughout brain regions, ${ }^{19}$ in line with in vitro studies of the 5HTTLPR. ${ }^{15,16}$ In humans, the 5-HTTLPR polymorphism has been poorly investigated in terms of serotonergic function. In healthy adults, no association has been observed between 5HTTLPR and its availability in the brain measured by positron emission computed tomography ${ }^{49}$ or the concentration of the serotonin metabolite 5-HIAA in the cerebrospinal fluid. ${ }^{50}$ It is likely that the influence of constitutive serotonin transporter reduction in the brain is mostly exerted during early development on neurogenesis and differentiation processes and then partly buffered or modified by other factors throughout development and aging, ${ }^{10,51,52}$ potentially explaining the non-additive effect observed at the molecular level in the present study.
The interaction between the serotonin transporter genotype and stress has been linked to depression, ${ }^{1-3}$ and sensitivity to early-life stressful events has been shown in $5-h t t^{ \pm}$male ${ }^{53}$ and female $^{54}$ rats. In the present study, emotional and physical neglect early in life was simulated by making use of the maternal separation model during the first postnatal weeks. ${ }^{55}$ Prolonged lack of maternal care can influence brain development negatively, as proven by its association with differential molecular, neuroendocrine, and behavioral outcomes ${ }^{56-58}$ of translational relevance to psychiatric outcomes in humans exposed to early life stressors. ${ }^{59,60}$ Although duration, frequency, timing, and regularity of maternal care disruption are factors that preclude comparisons between preclinical studies, ${ }^{58,61-63}$ maternal separation for $180 \mathrm{~min}$ during the first 2 postnatal weeks, as performed in the present study, is considered a valid stressor for the pups. ${ }^{64}$ Its occurrence during the so-called stress hypo-responsive period can disrupt the development of the HPA axis. ${ }^{65,66}$ However, as observed here, the effect of maternal separation may be buffered at the molecular level in individuals already genetically predisposed, such as 5-htt $t^{ \pm}$rats, to impaired HPA axis function. The present results, in fact, suggest a link between 5-HTT alterations and maternal separation as patterns of expression of stress-related genes in the hippocampus and frontal cortex of rats with constitutive serotonin transporter reduction resembled the ones displayed by rats exposed to maternal separation. This is in line with previous studies demonstrating an impact of maternal separation on serotonergic function. ${ }^{67-72}$ In the dorsal raphe nucleus, a region not investigated in the present study, lower expression of 5-htt mRNA has been found in rats exposed to maternal separation (MS180 ${ }^{67}$ and MS 15), ${ }^{68}$ and lower 5-HTT binding potential has been found in peer-reared monkeys exposed to maternal deprivation; ${ }^{72}$ these animals also showed depression and anxiety-like behavior. ${ }^{67,72}$ Moreover, postnatal treatment with clomipramine, leading to depressionlike behavior, has been associated with low 5-htt mRNA levels in the DRN. ${ }^{73}$ Further studies should investigate the combined effect of serotonin transporter reduction and maternal separation on behavioral and neural outcomes.

A stressful environmental factor was considered in the present study. Interestingly, various psychobiological theories have been applied to the 5-HTTLPRx environment field of research (e.g., the diathesis stress, ${ }^{74}$ vantage sensitivity, ${ }^{75}$ match and mismatch, ${ }^{76}$ differential susceptibility, ${ }^{77}$ and biological sensitivity to context) ${ }^{78}$ In line with the theories posited by Boyce and Belsky, ${ }^{77,78}$ the $\mathrm{S}$ allele of the serotonin transporter gene has been more recently suggested as a plasticity allele associated with increased sensitivity to protective and stressful environmental factors in relation to symptoms of depression. ${ }^{79,80}$ Indeed, depending on 5HTTLPR genotype, the same individual may thrive and suffer in the presence of supportive and aversive environmental influences, respectively, ${ }^{81}$ as recently demonstrated in monkeys carrying the short allele. ${ }^{82}$ A beneficial environment in rodents can be modeled by environmental enrichment, and its interactive effect with early life stress has recently been demonstrated on the pups' behavior and brain chemistry, ${ }^{83}$ thus calling for studies considering positive environmental factors as well.

Additionally, in contrast to previous studies, ${ }^{20}$ both sexes were here investigated, although no difference was observed between males and females. The serotonergic system as well as the stress system have been shown to interact with sex. ${ }^{84}$ For 
instance, lower serotonin synthesis rates have been found in the brain of females compared with males, ${ }^{85}$ and higher levels of the serotonin metabolite 5-HIAA have been observed in women carrying the $S$ allele. ${ }^{86}$ Moreover, studies of humans reported higher risk for depression, in the context of exposure to stressors, to be restricted to females carrying the $S$ allele of the 5-HTTLPR ${ }^{87-91}$ or that the $\mathrm{L}$ allele is the risk factors in males. $^{88,92-95}$ It could be plausible to hypothesize that behavioral outcomes measured following puberty may have differed between the sexes, as often observed in humans. ${ }^{96}$ Nevertheless, the present study found no sex difference at the molecular level when the stressor was applied in the first 2 postnatal weeks. Missing data on immobility-induced swim stress behavior could have informed us about differences in coping style. While this limits our interpretation, increased immobility behavior has been associated with a full 5-htt lossof-function mutation, independent of sex. ${ }^{97}$ However, in mice, no differences were found at basal levels or after a shockstressor in forced swim immobility time between 5-htt ${ }^{ \pm}$and 5$h t t^{+/+}$genotypes, ${ }^{98}$ although a tendency to reduced mobility time after prenatal stress exposure was found in female 5- $h t t t^{ \pm}$ compared with 5-htt ${ }^{+/+}$mice. ${ }^{99}$ Even though we cannot draw any conclusion from the forced swim test performed in the present study, it should be noted that the swim stress could have potentially affected the expression of the genes in the prefrontal cortex and hippocampus. As part of the test, rats were placed in water tanks for a total of $20 \mathrm{~min}$ (i.e., 15 during the induction phase on days 1 and 5 during the test day $24 \mathrm{~h}$ later). While the effects of housing, maternal separation, and other stressors on gene expression in the brain have been studied and demonstrated; the impact of such a time-limited experience remains to be investigated.

Conclusions. The present findings indicate differential expression of genes involved in the stress response system, neuroplasticity and catecholamine metabolism in the hippocampus and frontal cortex due to reduced serotonin transporter expression, maternal separation, or both, but independent of sex. No additive effect of serotonin transporter reduction and maternal separation on gene expression was found; such floor effects might explain inconsistent findings in humans and rodents.

\section{METHODS}

Animals. The study design is presented in Figure 1. Wild0type and heterozygous serotonin transporter knockout rats (Slc6a4 ${ }^{1 \mathrm{Hubr}}$, 5$h t t^{+/+}$and 5-htt ${ }^{ \pm}$) were derived from crossing female wild-type Wistar (WU, Harlan) with 5-htt ${ }^{ \pm}$and 5-htt ${ }^{-/-}$male rats (GenOway, Lyon, France). The pregnant dams were housed in standard polysulfone cages $(40 \mathrm{~cm} \times 20 \mathrm{~cm} \times 18 \mathrm{~cm})$ containing wood chip bedding material and two paper sheets $(40 \mathrm{~cm} \times 60 \mathrm{~cm}$; Cellstoff Papyrus $)$ as enrichment. Rats had ad libitum access to water and food (R36; Lantmännen, Kimstad, Sweden) in a temperature $\left(21 \pm 1{ }^{\circ} \mathrm{C}\right)$ and humidity-controlled room $(45 \%-60 \%$ relative humidity), with a 12 $\mathrm{h}$ light/dark cycle (lights on at 7:00 a.m.). The dams were inspected daily for delivery of pups at 5:00 p.m., and the day of birth was designated as post-natal day (PND) 1. All experimental procedures were approved by the Uppsala Animal Ethical Committee and followed the guidelines of the Swedish Legislation on Animal Experimentation (Animal Welfare Act SFS1998:56) and the European Communities Council Directive (86/609/EEC).

Maternal Separation. Litters were randomly allocated to one of two rearing conditions (from PND 2 to 15): maternal separation for $180 \mathrm{~min}$ (MS180) or no maternal separation (MS0). MS180 was started daily between 8:30 and 9:00 a.m. and was performed as follows: the pups were removed from the home cage and placed as a whole litter into a smaller cage $(24 \mathrm{~cm} \times 15 \mathrm{~cm} \times 14 \mathrm{~cm})$ with only sawdust bedding after which they were transferred to a temperature incubator in adjacent room. The temperature was set to maintain a temperature of $29 \pm 1{ }^{\circ} \mathrm{C}$. At the end of the separation period, litters were returned to their home cage by placing them in the nest and covering them with home cage bedding material. Home cages were refreshed at PND 7 and 14. At PND 21, ear punches were taken of the pups for identification and genotyping. At PND28, the pups were weaned and housed in groups of three to four littermates of the same sex and rearing conditions under the same conditions as mentioned above.

Genomic DNA Isolation. Ear punches were lysed overnight in $400 \mu \mathrm{L}$ of lysis buffer containing $100 \mathrm{mM}$ Tris (pH 8.5), $200 \mathrm{mM}$ of $\mathrm{NaCl}, 0.2 \%$ of sodium dodecyl sulfate (SDS), $5 \mathrm{mM}$ of ethylene diamine tetraacetic acid (EDTA), and $100 \mu \mathrm{g} / \mathrm{mL}$ of freshly added proteinase $\mathrm{K}$ at $55^{\circ} \mathrm{C}$. The next day, proteinase $\mathrm{K}$ activity was ended by $10 \mathrm{~min}$ incubation at $80{ }^{\circ} \mathrm{C}$. Samples were cooled and shortly centrifuged to collect condensate. DNA was precipitated by adding $400 \mu \mathrm{L}$ of isopropanol, mixing by inversion, followed by centrifuging for $10 \mathrm{~min}$ at $14000 \mathrm{~g}$. The supernatant was removed by gently inverting the tube and the pellets were washed with $300 \mu \mathrm{L} 70 \%$ ethanol and centrifuged for $5 \mathrm{~min}$ at $14000 \mathrm{~g}$. The supernatant was discarded with a pipet, the pellet was air-dried, and the DNA solved in $100 \mu \mathrm{L}$ of TE-buffer by incubating $10 \mathrm{~min}$ at $70^{\circ} \mathrm{C}$ and vortexing.

Genotyping. The following primers and probes were used: forward primer of 5'-GCACGAACTCCTGGAACACT, reverse primer of 5 'AGCGTCCAGGTGATGTTGTC, serotonin wild-type probe of 6FAM-AGTTGGTGCAGTTGC-MGBNFQ and serotonin transporter knockout probe of VIC-AGTAGTTGGTTCAGTTGCMGBNFQ (solved in $20 \times$ primer solution, Life technologies, Sweden). Genotyping was performed using Applied Biosystem Step One Plus (Life technologies, Sweden). The total reaction was $25 \mu \mathrm{L}$ containing $12.5 \mu \mathrm{L}$ of Taqman Universal Mastermix II, no UNG (catalog no. 4440047, Life Technologies, Sweden); $1.25 \mu \mathrm{L}$ of $20 \times$ primer solution; $10.25 \mu \mathrm{L}$ of sterile $\mathrm{H}_{2} \mathrm{O}$, and $1 \mu \mathrm{L}$ of DNA sample. The thermal cycling for genotyping was as follows: $95{ }^{\circ} \mathrm{C}$ for $10 \mathrm{~min}$ plus $40 \times\left(92{ }^{\circ} \mathrm{C}\right.$ for $15 \mathrm{~s}$ and $60^{\circ} \mathrm{C}$ for $\left.1 \mathrm{~min}\right)$. Genotypes, $5-h t t^{+/+}$ and $5-h t t^{ \pm}$, were manually inspected by comparing them with positive controls.

Tissue Collection. A forced swim test was performed at day 84 (15 $\mathrm{min})$ and day $85(5 \mathrm{~min})$ to address immobility. A total of 2 weeks after the forced swim test, at PND98, rats were sacrificed by decapitation. Rats were taken from their home cage into a separate room and decapitated within $10 \mathrm{~s}$. Immediately after decapitation, the frontal cortex [brains were put in a brain grid, and the frontal part of the brain was cut at approximately Bregma $3.20 \mathrm{~mm}$ (Paxinos and Watson Atlas); subsequently, the PRL/CG1/M2 part was roughly dissected] and hippocampus were isolated and immediately frozen in liquid nitrogen and stored at $-80{ }^{\circ} \mathrm{C}$ until further use. Note: half of the videos for the forced swim test cannot be retrieved due to saving errors. Therefore, data of the forced swim test are not shown.

Total RNA Isolation. Total RNA was isolated from brain tissue using an RNeasy lipid tissue mini kit (catalog no. 74804; Qiagen, Hilden, Germany) according to the manufacturer's instructions. RNA concentration was measured using an ND-1000 spectrophotometer (NanoDrop Technologies, Wilmington, DE), and RNA quality was evaluated using the Agilent 2100 Bioanalyzer system (Agilent Technologies Inc., Palo Alto, CA).

CDNA Synthesis. Total RNA (250 ng) from each sample was used to generate complementary DNA (cDNA) using Superscript VILO Mastermix (catalog no. 11755-250; Invitrogen, Carlsbad, CA) according to the manufacturer's protocol. Briefly, $4 \mu \mathrm{L}$ of Superscript VILO Mastermix was added to $250 \mathrm{ng}$ of RNA and filled to a volume of $20 \mu \mathrm{L}$ with diethylpyrocarbonate (DEPC)-treated water. The thermal cycling for cDNA synthesis was as follows: $25{ }^{\circ} \mathrm{C}$ for $10 \mathrm{~min}$ plus $42{ }^{\circ} \mathrm{C}$ for $60 \mathrm{~min}$ plus $85^{\circ} \mathrm{C}$ for $5 \mathrm{~min}$. The cDNA samples were stored at $-20{ }^{\circ} \mathrm{C}$ until quantitative polymerase chain reaction (PCR) analysis.

Quantitative PCR. The relative expression of Avp, Pomc, Crh, Crhbp, Crhr1, Bdnf, Ntrk2, Maoa, Maob, and Comt was investigated. 
Quantitative PCR (qPCR) reactions were carried out in a Step One Plus real-time PCR system (Applied Biosystems, Foster City, CA). Reactions were performed in MicroAmp Fast Optical 96-Well Reaction Plate with Barcode, $0.1 \mathrm{~mL}$, and appropriate MicroAmp optical adhesive film (Applied Biosystems, Foster City, CA). The reaction mixture consisted of $10 \mu \mathrm{L}$ of TaqMan gene expression Mastermix (Applied Biosystems, Foster City, CA), 1.0 $\mu \mathrm{L}$ of cDNA, and $1 \mu \mathrm{L}$ of $20 \times$ primers (Life Technologies). The final reaction volume was $20 \mu \mathrm{L}$. The thermal cycling for quantitative PCR was as follows: stage $1,2 \mathrm{~min}$ at $50^{\circ} \mathrm{C}$ plus $10 \mathrm{~min}$ at $95^{\circ} \mathrm{C}$ and stage 2,55 cycles of denaturation at $95{ }^{\circ} \mathrm{C}$ for $15 \mathrm{~s}$ and combined primer annealing and extension at $60^{\circ} \mathrm{C}$ for $1 \mathrm{~min}$. The primers are shown in Table S1.

Relative fluorescence values were converted into quantification cycle $\left(C_{\mathrm{q}}\right)$ values, the cycle at which the gene reached a detection threshold, controlling for batch effects. The LinReg software ${ }^{100}$ was used to compute the batch-averaged baseline and qPCR efficiencies (Table S2). $C_{\mathrm{q}}$ values were adjusted across the plates using correction factors derived from threshold and PCR efficiency values. Each sample was run in triplicates. Samples with normalized $C_{\mathrm{q}}$ values that had a standard deviation of more than 0.5 were excluded. Following computation of the average of the triplicates for each sample, the mean of the average of both reference genes (Gapdh and Ywhaz) was used to estimate the reference $\mathrm{Ct}$ values. Relative gene transcripts levels were determined using the $\triangle \mathrm{CT}$ method (Real-Time PCR Applications Guide, Bio-Rad). All of the laboratory and preprocessing analyses were performed in a blind manner. Valid gene expression data were retrieved for the frontal cortex of $n=4$ female MS0-5-htt ${ }^{+/+}, n=6$ female MS0-5-htt ${ }^{ \pm,} n=8$ female MS-5-htt ${ }^{+/+}, n=8$ female MS-5-htt ${ }^{ \pm} n=6$ male MS0-5- $h t t^{+/+}, n=6$ male MS0-5- $h t t$ ${ }^{ \pm}, n=9$ male MS-5-htt ${ }^{+/+}$, and $n=6$ male MS-5-htt ${ }^{ \pm}$rats and for the hippocampus of $n=4$ female MSO-5-htt ${ }^{+/+}, n=5$ female MS0-5-htt ${ }^{ \pm}, n=6$ female MS $-5-h t t^{+/+}, n=8$ female MS $-5-h t t{ }^{ \pm}, n=6$ male MS0-5- $h \mathrm{tt}^{+/+}, n=6$ male MS0-5-htt ${ }^{ \pm}, n=9$ male MS-5-htt ${ }^{+/+}$, and $n=10$ male MS-5-htt ${ }^{ \pm}$rats.

Statistical Analyses. The Statistical Package for the Social Sciences (SPSS) software version 22 (SPPS Inc., IBM SPSS Statistics, Chicago) was used for statistics analyses. Normality of the gene expression data was tested using the Shapiro Wilk test. Nonparametric tests were performed to account for deviation from normal distribution. Differences in gene expression between groups were assessed using the Kruskal-Wallis and Mann-Whitney $U$ tests. Interactions effects between rearing conditions, genotype and sex on gene expression were tested using the general linear model (GLM) with type III sum of squares. Correlations between the expression of the genes were analyzed using the Spearman correlation test. Correction for multiple comparisons was performed using Bonferroni correction.

\section{ASSOCIATED CONTENT}

\section{S Supporting Information}

The Supporting Information is available free of charge on the ACS Publications website at DOI: 10.1021/acschemneur$0.8 \mathrm{~b} 00595$.

Tables showing the specifics of TaqMan gene expression assays and mean qPCR efficiency and $\mathrm{Cq}$ range for the genes of interest; Figures showing pair-wise, nominally significant differences in relative gene expression observed between male and female $5-\mathrm{htt}^{+/+}$rats not exposed to maternal separation and the other experimental groups, maternal separation-driven relative gene expression differences in $5-\mathrm{htt}^{+/+}$rats, serotonin-transporter genotype-driven relative gene expression differences in rats not exposed to maternal separation, and correlations heat maps of relative gene expression by experimental group and sex (PDF)

\section{AUTHOR INFORMATION}

\section{Corresponding Authors}

*E-mail: erika.comasco@neuro.uu.se; +46-18-471-5020.

*E-mail: j.d.a.olivier@rug.nl; phone: +31-50-363-7221.

ORCID

Erika Comasco: 0000-0002-2174-2068

\section{Author Contributions}

J.D.A.O. and I.S.P. contributed to the study design. J.D.A.O. contributed to the animal experiments. D.S. and H.D.M. contributed to RNA isolation. D.S., H.D.M., and M.V. contributed to the gene expression analyses. E.C. contributed to statistical analyses and the manuscript draft. J.O., I.N., and I.S.P. contributed to critical revision of the manuscript. All authors contributed to the finalization and approval of the content of the manuscript.

\section{Funding}

The study was partially supported by funds from the Swedish Society of Medicine (SLS-411161) to J.D.A.O.; the Fredrik and Ingrid Thuring Foundation (2012-2014), the Lars Hierta's Minne Foundation (2013), and the Alcohol Research Council of the Swedish Alcohol Retailing Monopoly (2016020) to E.C.; and from the Alcohol Research Council of the Swedish Alcohol Retailing Monopoly, the European Foundation for Alcohol Research (EA 11 30), the Swedish Research Council (K2012-61X-22090-01-3) to I.N. E.C. is a Marie Skłodowska Curie fellow and received funds from the Swedish Research Council (VR: 2015-00495) and the EU FP7-PeopleCofund (INCA 600398), as well as SciLifeLab. The funding body had no role in the design of the study, collection, and analysis of data and decision to publish.

\section{Notes}

The authors declare no competing financial interest.

\section{REFERENCES}

(1) Caspi, A., Sugden, K., Moffitt, T. E., Taylor, A., Craig, I. W., Harrington, H., McClay, J., Mill, J., Martin, J., Braithwaite, A., and Poulton, R. (2003) Influence of life stress on depression: moderation by a polymorphism in the 5-HTT gene. Science 301, 386-389.

(2) Karg, K., Burmeister, M., Shedden, K., and Sen, S. (2011) The serotonin transporter promoter variant (5-HTTLPR), stress, and depression meta-analysis revisited: evidence of genetic moderation. Arch. Gen. Psychiatry 68, 444-454.

(3) Culverhouse, R. C., Saccone, N. L., Horton, A. C., Ma, Y., Anstey, K. J., Banaschewski, T., Burmeister, M., Cohen-Woods, S., Etain, B., Fisher, H. L., Goldman, N., Guillaume, S., Horwood, J., Juhasz, G., Lester, K. J., Mandelli, L., Middeldorp, C. M., Olie, E., Villafuerte, S., Air, T. M., Araya, R., Bowes, L., Burns, R., Byrne, E. M., Coffey, C., Coventry, W. L., Gawronski, K. A., Glei, D., Hatzimanolis, A., Hottenga, J. J., Jaussent, I., Jawahar, C., Jennen-Steinmetz, C., Kramer, J. R., Lajnef, M., Little, K., Zu Schwabedissen, H. M., Nauck, M., Nederhof, E., Petschner, P., Peyrot, W. J., Schwahn, C., Sinnamon, G., Stacey, D., Tian, Y., Toben, C., Van der Auwera, S., Wainwright, N., Wang, J. C., Willemsen, G., Anderson, I. M., Arolt, V., Aslund, C., Bagdy, G., Baune, B. T., Bellivier, F., Boomsma, D. I., Courtet, P., Dannlowski, U., de Geus, E. J., Deakin, J. F., Easteal, S., Eley, T., Fergusson, D. M., Goate, A. M., Gonda, X., Grabe, H. J., Holzman, C., Johnson, E. O., Kennedy, M., Laucht, M., Martin, N. G., Munafo, M. R., Nilsson, K. W., Oldehinkel, A. J., Olsson, C. A., Ormel, J., Otte, C., Patton, G. C., Penninx, B. W., Ritchie, K., Sarchiapone, M., Scheid, J. M., Serretti, A., Smit, J. H., Stefanis, N. C., Surtees, P. G., Volzke, H., Weinstein, M., Whooley, M., Nurnberger, J. I., Breslau, N., and Bierut, L. J. (2018) Collaborative meta-analysis finds no evidence of a strong interaction between stress and 5-HTTLPR genotype contributing to the development of depression. Mol. Psychiatry 23, 133. 
(4) Caspi, A., Hariri, A. R., Holmes, A., Uher, R., and Moffitt, T. E. (2010) Genetic sensitivity to the environment: the case of the serotonin transporter gene and its implications for studying complex diseases and traits. Am. J. Psychiatry 167, 509-527.

(5) Hariri, A. R., Mattay, V. S., Tessitore, A., Kolachana, B., Fera, F., Goldman, D., Egan, M. F., and Weinberger, D. R. (2002) Serotonin transporter genetic variation and the response of the human amygdala. Science 297, 400-403.

(6) Bennett, A. J., Lesch, K. P., Heils, A., Long, J. C., Lorenz, J. G., Shoaf, S. E., Champoux, M., Suomi, S. J., Linnoila, M. V., and Higley, J. D. (2002) Early experience and serotonin transporter gene variation interact to influence primate CNS function. Mol. Psychiatry 7, 118122.

(7) Canli, T., and Lesch, K. P. (2007) Long story short: the serotonin transporter in emotion regulation and social cognition. Nat. Neurosci. 10, 1103-1109.

(8) Flint, J., and Kendler, K. S. (2014) The genetics of major depression. Neuron 81, 484-503.

(9) Curley, J. P., and Champagne, F. A. (2016) Influence of maternal care on the developing brain: Mechanisms, temporal dynamics and sensitive periods. Front. Neuroendocrinol. 40, 52-66.

(10) Teissier, A., Soiza-Reilly, M., and Gaspar, P. (2017) Refining the Role of 5-HT in Postnatal Development of Brain Circuits. Front. Cell. Neurosci. 11, 139.

(11) Maccari, S., Krugers, H. J., Morley Fletcher, S., Szyf, M., and Brunton, P. J. (2014) The Consequences of Early Life Adversity: Neurobiological, Behavioural and Epigenetic Adaptations. J. Neuroendocrinol. 26, 707-723.

(12) Kokras, N., and Dalla, C. (2017) Preclinical sex differences in depression and antidepressant response: Implications for clinical research. J. Neurosci. Res. 95, 731-736.

(13) Ilyas, S., and Moncrieff, J. (2012) Trends in prescriptions and costs of drugs for mental disorders in England, 1998-2010. Br. J. Psychiatry 200, 393-398.

(14) Crawford, A. A., Lewis, G., Lewis, S. J., and Munafo, M. R. (2013) Systematic review and meta-analysis of serotonin transporter genotype and discontinuation from antidepressant treatment. Eur. Neuropsychopharmacol. 23, 1143-1150.

(15) Heils, A., Teufel, A., Petri, S., Stober, G., Riederer, P., Bengel, D., and Lesch, K. P. (1996) Allelic variation of human serotonin transporter gene expression. J. Neurochem. 66, 2621-2624.

(16) Lesch, K. P., Bengel, D., Heils, A., Sabol, S. Z., Greenberg, B. D., Petri, S., Benjamin, J., Muller, C. R., Hamer, D. H., and Murphy, D. L. (1996) Association of anxiety-related traits with a polymorphism in the serotonin transporter gene regulatory region. Science 274, 1527-1531.

(17) Bengel, D., Heils, A., Petri, S., Seemann, M., Glatz, K., Andrews, A., Murphy, D. L., and Lesch, K. P. (1997) Gene structure and 5'flanking regulatory region of the murine serotonin transporter. Mol. Brain Res. 44, 286-292.

(18) Smits, B. M., Mudde, J. B., van de Belt, J., Verheul, M., Olivier, J., Homberg, J., Guryev, V., Cools, A. R., Ellenbroek, B. A., Plasterk, R. H., and Cuppen, E. (2006) Generation of gene knockouts and mutant models in the laboratory rat by ENU-driven target-selected mutagenesis. Pharmacogenet Genomics 16, 159-169.

(19) Homberg, J. R., Olivier, J. D., Smits, B. M., Mul, J. D., Mudde, J., Verheul, M., Nieuwenhuizen, O. F., Cools, A. R., Ronken, E., Cremers, T., Schoffelmeer, A. N., Ellenbroek, B. A., and Cuppen, E. (2007) Characterization of the serotonin transporter knockout rat: a selective change in the functioning of the serotonergic system. Neuroscience 146, 1662-1676.

(20) Houwing, D. J., Buwalda, B., van der Zee, E. A., de Boer, S. F., and Olivier, J. D. A. (2017) The Serotonin Transporter and Early Life Stress: Translational Perspectives. Front. Cell. Neurosci. 11, 117.

(21) Ulrich-Lai, Y. M., and Herman, J. P. (2009) Neural regulation of endocrine and autonomic stress responses. Nat. Rev. Neurosci. 10, 397-409.

(22) Charmandari, E., Tsigos, C., and Chrousos, G. (2005) Endocrinology of the stress response. Annu. Rev. Physiol. 67, 259-284.
(23) Duncan, L. E., and Keller, M. C. (2011) A critical review of the first 10 years of candidate gene-by-environment interaction research in psychiatry. Am. J. Psychiatry 168, 1041-1049.

(24) Arnsten, A. F. (2009) Stress signalling pathways that impair prefrontal cortex structure and function. Nat. Rev. Neurosci. 10, 410422.

(25) Wellman, C. L. (2001) Dendritic reorganization in pyramidal neurons in medial prefrontal cortex after chronic corticosterone administration. J. Neurobiol. 49, 245-253.

(26) Molteni, R., Cattaneo, A., Calabrese, F., Macchi, F., Olivier, J. D., Racagni, G., Ellenbroek, B. A., Gennarelli, M., and Riva, M. A. (2010) Reduced function of the serotonin transporter is associated with decreased expression of BDNF in rodents as well as in humans. Neurobiol. Dis. 37, 747-755.

(27) Calabrese, F., van der Doelen, R. H., Guidotti, G., Racagni, G., Kozicz, T., Homberg, J. R., and Riva, M. A. (2015) Exposure to early life stress regulates Bdnf expression in SERT mutant rats in an anatomically selective fashion. J. Neurochem. 132, 146-154.

(28) Martinowich, K., and Lu, B. (2008) Interaction between BDNF and serotonin: role in mood disorders. Neuropsychopharmacology 33, $73-83$.

(29) Zhou, C., Zhong, J., Zou, B., Fang, L., Chen, J., Deng, X., Zhang, L., Zhao, X., Qu, Z., Lei, Y., and Lei, T. (2017) Meta-analyses of comparative efficacy of antidepressant medications on peripheral BDNF concentration in patients with depression. PLoS One 12, No. e0172270.

(30) Homberg, J. R., Molteni, R., Calabrese, F., and Riva, M. A. (2014) The serotonin-BDNF duo: developmental implications for the vulnerability to psychopathology. Neurosci. Biobehav. Rev. 43, 35-47.

(31) Carola, V., Frazzetto, G., Pascucci, T., Audero, E., PuglisiAllegra, S., Cabib, S., Lesch, K. P., and Gross, C. (2008) Identifying molecular substrates in a mouse model of the serotonin transporter $\mathrm{x}$ environment risk factor for anxiety and depression. Biol. Psychiatry 63, 840-846.

(32) Daskalakis, N. P., De Kloet, E. R., Yehuda, R., Malaspina, D., and Kranz, T. M. (2015) Early Life Stress Effects on GlucocorticoidBDNF Interplay in the Hippocampus. Front. Mol. Neurosci. 8, 68.

(33) Jiang, X., Wang, J., Luo, T., and Li, Q. (2009) Impaired hypothalamic-pituitary-adrenal axis and its feedback regulation in serotonin transporter knockout mice. Psychoneuroendocrinology 34, $317-331$

(34) van der Doelen, R. H., Arnoldussen, I. A., Ghareh, H., van Och, L., Homberg, J. R., and Kozicz, T. (2015) Early life adversity and serotonin transporter gene variation interact to affect DNA methylation of the corticotropin-releasing factor gene promoter region in the adult rat brain. Dev Psychopathol 27, 123-135.

(35) Smith, S. M., and Vale, W. W. (2006) The role of the hypothalamic-pituitary-adrenal axis in neuroendocrine responses to stress. Dialogues in clinical neuroscience 8, 383-395.

(36) Plotsky, P. M., and Meaney, M. J. (1993) Early, postnatal experience alters hypothalamic corticotropin-releasing factor (CRF) mRNA, median eminence CRF content and stress-induced release in adult rats. Mol. Brain Res. 18, 195-200.

(37) Reyes, B. A., Valentino, R. J., and Van Bockstaele, E. J. (2008) Stress-induced intracellular trafficking of corticotropin-releasing factor receptors in rat locus coeruleus neurons. Endocrinology 149, 122-130.

(38) O’Malley, D., Dinan, T. G., and Cryan, J. F. (2011) Neonatal maternal separation in the rat impacts on the stress responsivity of central corticotropin-releasing factor receptors in adulthood. Psychopharmacology (Berl) 214, 221-229.

(39) Sutton, S. W., Behan, D. P., Lahrichi, S. L., Kaiser, R., Corrigan, A., Lowry, P., Potter, E., Perrin, M. H., Rivier, J., and Vale, W. W. (1995) Ligand requirements of the human corticotropin-releasing factor-binding protein. Endocrinology 136, 1097-1102.

(40) Seasholtz, A. F., Valverde, R. A., and Denver, R. J. (2002) Corticotropin-releasing hormone-binding protein: biochemistry and function from fishes to mammals. J. Endocrinol. 175, 89-97.

(41) Evans, J., Xu, K., Heron, J., Enoch, M. A., Araya, R., Lewis, G., Timpson, N., Davies, S., Nutt, D., and Goldman, D. (2009) 
Emotional symptoms in children: The effect of maternal depression, life events, and COMT genotype. Am. J. Med. Genet., Part B 150B, 209-218.

(42) Lachman, H. M., Papolos, D. F., Saito, T., Yu, Y. M., Szumlanski, C. L., and Weinshilboum, R. M. (1996) Human catecholO-methyltransferase pharmacogenetics: description of a functional polymorphism and its potential application to neuropsychiatric disorders. Pharmacogenetics 6, 243-250.

(43) Thompson, J. M., Sonuga-Barke, E. J., Morgan, A. R., Cornforth, C. M., Turic, D., Ferguson, L. R., Mitchell, E. A., and Waldie, K. E. (2012) The catechol-O-methyltransferase (COMT) Val158Met polymorphism moderates the effect of antenatal stress on childhood behavioural problems: longitudinal evidence across multiple ages. Dev Med. Child Neurol 54, 148-154.

(44) Shih, J. C., Chen, K., and Ridd, M. J. (1999) Monoamine oxidase: from genes to behavior. Annu. Rev. Neurosci. 22, 197-217.

(45) Singh, C., Bortolato, M., Bali, N., Godar, S. C., Scott, A. L., Chen, K., Thompson, R. F., and Shih, J. C. (2013) Cognitive abnormalities and hippocampal alterations in monoamine oxidase $\mathrm{A}$ and B knockout mice. Proc. Natl. Acad. Sci. U. S. A. 110, 1281612821 .

(46) Amara, S. G., and Kuhar, M. J. (1993) Neurotransmitter transporters: recent progress. Annu. Rev. Neurosci. 16, 73-93.

(47) Suomi, S. J. (2006) Risk, resilience, and gene $\mathrm{x}$ environment interactions in rhesus monkeys. Ann. N. Y. Acad. Sci. 1094, 52-62.

(48) Barr, C. S., Newman, T. K., Becker, M. L., Parker, C. C., Champoux, M., Lesch, K. P., Goldman, D., Suomi, S. J., and Higley, J. D. (2003) The utility of the non-human primate; model for studying gene by environment interactions in behavioral research. Genes, Brain Behav. 2, 336-340.

(49) Parsey, R. V., Hastings, R. S., Oquendo, M. A., Hu, X., Goldman, D., Huang, Y. Y., Simpson, N., Arcement, J., Huang, Y., Ogden, R. T., Van Heertum, R. L., Arango, V., and Mann, J. J. (2006) Effect of a triallelic functional polymorphism of the serotonintransporter-linked promoter region on expression of serotonin transporter in the human brain. Am. J. Psychiatry 163, 48-51.

(50) Jonsson, E. G., Nothen, M. M., Gustavsson, J. P., Neidt, H., Bunzel, R., Propping, P., and Sedvall, G. C. (1998) Polymorphisms in the dopamine, serotonin, and norepinephrine transporter genes and their relationships to monoamine metabolite concentrations in CSF of healthy volunteers. Psychiatry Res. 79, 1-9.

(51) Gaspar, P., Cases, O., and Maroteaux, L. (2003) The developmental role of serotonin: news from mouse molecular genetics. Nat. Rev. Neurosci. 4, 1002-1012.

(52) Nordquist, N., and Oreland, L. (2010) Serotonin, genetic variability, behaviour, and psychiatric disorders-a review. Upsala J. Med. Sci. 115, 2-10.

(53) van der Doelen, R. H., Kozicz, T., and Homberg, J. R. (2013) Adaptive fitness; early life adversity improves adult stress coping in heterozygous serotonin transporter knockout rats. Mol. Psychiatry 18, $1244-1245$.

(54) Houwing, D. J., Ramsteijn, A. S., Riemersma, I. W., and Olivier, J. D. A. (2019) Maternal separation induces anhedonia in female heterozygous serotonin transporter knockout rats. Behav. Brain Res. 356, 204-207.

(55) Pryce, C. R., and Feldon, J. (2003) Long-term neurobehavioural impact of the postnatal environment in rats: manipulations, effects and mediating mechanisms. Neurosci. Biobehav. Rev. 27, $57-71$.

(56) Maccari, S., Krugers, H. J., Morley-Fletcher, S., Szyf, M., and Brunton, P. J. (2014) The consequences of early-life adversity: neurobiological, behavioural and epigenetic adaptations. J. Neuroendocrinol. 26, 707-723.

(57) Meaney, M. J. (2001) Maternal care, gene expression, and the transmission of individual differences in stress reactivity across generations. Annu. Rev. Neurosci. 24, 1161-1192.

(58) Lehmann, J., and Feldon, J. (2000) Long-term biobehavioral effects of maternal separation in the rat: consistent or confusing? Rev. Neurosci. 11, 383-408.
(59) Teicher, M. H., Tomoda, A., and Andersen, S. L. (2006) Neurobiological consequences of early stress and childhood maltreatment: are results from human and animal studies comparable? Ann. N. Y. Acad. Sci. 1071, 313-323.

(60) Gilbert, R., Widom, C. S., Browne, K., Fergusson, D., Webb, E., and Janson, S. (2009) Burden and consequences of child maltreatment in high-income countries. Lancet 373, 68-81.

(61) Molet, J., Maras, P. M., Avishai-Eliner, S., and Baram, T. Z. (2014) Naturalistic rodent models of chronic early-life stress. Developmental psychobiology 56, 1675-1688.

(62) Macri, S., Mason, G. J., and Wurbel, H. (2004) Dissociation in the effects of neonatal maternal separations on maternal care and the offspring's HPA and fear responses in rats. Eur. J. Neurosci 20, 10171024.

(63) Plotsky, P. M., Thrivikraman, K. V., Nemeroff, C. B., Caldji, C., Sharma, S., and Meaney, M. J. (2005) Long-Term Consequences of Neonatal Rearing on Central Corticotropin-Releasing Factor Systems in Adult Male Rat Offspring. Neuropsychopharmacology 30, $2192-$ 2204.

(64) Pryce, C. R., and Feldon, J. (2003) Long-term neurobehavioural impact of the postnatal environment in rats: manipulations, effects and mediating mechanisms. Neurosci. Biobehav. Rev. 27, $57-71$.

(65) Levine, S. (1994) The ontogeny of the hypothalamic-pituitaryadrenal axis. The influence of maternal factors. Ann. N. Y. Acad. Sci. 746, 275-288 discussion 289-293 .

(66) Sapolsky, R. M., and Meaney, M. J. (1986) Maturation of the adrenocortical stress response: Neuroendocrine control mechanisms and the stress hyporesponsive period. Brain Res. Rev. 11, 65-76.

(67) Lee, J. H., Kim, H. J., Kim, J. G., Ryu, V., Kim, B. T., Kang, D. W., and Jahng, J. W. (2007) Depressive behaviors and decreased expression of serotonin reuptake transporter in rats that experienced neonatal maternal separation. Neurosci. Res. 58, 32-39.

(68) Oreland, S., Pickering, C., Gokturk, C., Oreland, L., Arborelius, L., and Nylander, I. (2009) Two repeated maternal separation procedures differentially affect brain 5-hydroxytryptamine transporter and receptors in young and adult male and female rats. Brain Res. 1305, S37-49.

(69) Oreland, S., Raudkivi, K., Oreland, L., Harro, J., Arborelius, L., and Nylander, I. (2011) Ethanol-induced effects on the dopamine and serotonin systems in adult Wistar rats are dependent on early-life experiences. Brain Res. 1405, 57-68.

(70) Arborelius, L., Hawks, B. W., Owens, M. J., Plotsky, P. M., and Nemeroff, C. B. (2004) Increased responsiveness of presumed 5-HT cells to citalopram in adult rats subjected to prolonged maternal separation relative to brief separation. Psychopharmacology (Berl) 176, 248-255.

(71) Arborelius, L., and Eklund, M. B. (2007) Both long and brief maternal separation produces persistent changes in tissue levels of brain monoamines in middle-aged female rats. Neuroscience 145, 738750 .

(72) Ichise, M., Vines, D. C., Gura, T., Anderson, G. M., Suomi, S. J., Higley, J. D., and Innis, R. B. (2006) Effects of early life stress on [11C]DASB positron emission tomography imaging of serotonin transporters in adolescent peer- and mother-reared rhesus monkeys. J. Neurosci. 26, 4638-4643.

(73) Hansen, H. H., and Mikkelsen, J. D. (1998) Long-term effects on serotonin transporter mRNA expression of chronic neonatal exposure to a serotonin reuptake inhibitor. Eur. J. Pharmacol. 352, $307-315$.

(74) Zuckerman, M. (1999) Diathesis-stress models. In Vulnerability to psychopathology: A biosocial model; pp 3-23, American Psychological Association, Washington, DC, US.

(75) Pluess, M., and Belsky, J. (2013) Vantage sensitivity: Individual differences in response to positive experiences. Psychological Bulletin 139, 901-916.

(76) Homberg, J. R. (2012) The stress-coping (mis)match hypothesis for nature x nurture interactions. Brain Res. 1432, 114121. 
(77) Belsky, J., Bakermans-Kranenburg, M. J., and van IJzendoorn, M. H. (2007) For Better and For Worse: Differential Susceptibility to Environmental Influences. Current Directions in Psychological Science $16,300-304$.

(78) Boyce, W. T., and Ellis, B. J. (2005) Biological sensitivity to context: I. An evolutionary-developmental theory of the origins and functions of stress reactivity. Development and psychopathology 17, 271-301.

(79) Kaufman, J., Yang, B.-Z., Douglas-Palumberi, H., Houshyar, S., Lipschitz, D., Krystal, J. H., and Gelernter, J. (2004) Social supports and serotonin transporter gene moderate depression in maltreated children. Proc. Natl. Acad. Sci. U. S. A. 101, 17316-17321.

(80) Aslund, C., and Nilsson, K. W. (2018) Individual biological sensitivity to environmental influences: testing the differential susceptibility properties of the 5HTTLPR polymorphism in relation to depressive symptoms and delinquency in two adolescent general samples. J. Neural Transm (Vienna) 125, 977-993.

(81) Pluess, M. (2015) Individual Differences in Environmental Sensitivity. Child Development Perspectives 9, 138-143.

(82) Madrid, J. E., Mandalaywala, T. M., Coyne, S. P., AhloyDallaire, J., Garner, J. P., Barr, C. S., Maestripieri, D., and Parker, K. J. (2018) Adaptive developmental plasticity in rhesus macaques: the serotonin transporter gene interacts with maternal care to affect juvenile social behaviour. Proc. R. Soc. London, Ser. B 285, 285.

(83) Bodden, C., van den Hove, D., Lesch, K. P., and Sachser, N. (2017) Impact of varying social experiences during life history on behaviour, gene expression, and vasopressin receptor gene methylation in mice. Sci. Rep. 7, 8719.

(84) Perry, L. M., Goldstein-Piekarski, A. N., and Williams, L. M. (2017) Sex differences modulating serotonergic polymorphisms implicated in the mechanistic pathways of risk for depression and related disorders. J. Neurosci. Res. 95, 737-762.

(85) Nishizawa, S., Benkelfat, C., Young, S. N., Leyton, M., Mzengeza, S., de Montigny, C., Blier, P., and Diksic, M. (1997) Differences between males and females in rates of serotonin synthesis in human brain. Proc. Natl. Acad. Sci. U. S. A. 94, 5308-5313.

(86) Williams, R. B., Marchuk, D. A., Gadde, K. M., Barefoot, J. C., Grichnik, K., Helms, M. J., Kuhn, C. M., Lewis, J. G., Schanberg, S. M., Stafford-Smith, M., Suarez, E. C., Clary, G. L., Svenson, I. K., and Siegler, I. C. (2003) Serotonin-related gene polymorphisms and central nervous system serotonin function. Neuropsychopharmacology 28, 533-541.

(87) Brummett, B. H., Boyle, S. H., Siegler, I. C., Kuhn, C. M., Ashley-Koch, A., Jonassaint, C. R., Züchner, S., Collins, A., and Williams, R. B. (2008) Effects of environmental stress and gender on associations among symptoms of depression and the serotonin transporter gene linked polymorphic region (5-HTTLPR). Behav. Genet. 38, 34-43.

(88) Sjoberg, R. L., Nilsson, K. W., Nordquist, N., Öhrvik, J., Leppert, J., Lindström, L., and Oreland, L. (2006) Development of depression - sex and the interaction between environment and promoter polymorphism of the serotonin transporter gene. Int. J. Neuropsychopharmacol. 9 (Sep), 1-7.

(89) Eley, T. C., Sugden, K., Corsico, A., Gregory, A. M., Sham, P., McGuffin, P., Plomin, R., and Craig, I. W. (2004) Gene-environment interaction analysis of serotonin system markers with adolescent depression. Mol. Psychiatry 9, 908-915.

(90) Grabe, H. J., Lange, M., Wolff, B., Volzke, H., Lucht, M., Freyberger, H. J., John, U., and Cascorbi, I. (2005) Mental and physical distress is modulated by a polymorphism in the 5-HT transporter gene interacting with social stressors and chronic disease burden. Mol. Psychiatry 10, 220-224.

(91) Aslund, C., Leppert, J., Comasco, E., Nordquist, N., Oreland, L., and Nilsson, K. W. (2009) Impact of the interaction between the 5HTTLPR polymorphism and maltreatment on adolescent depression. A population-based study. Behav. Genet. 39, 524-531.

(92) Brummett, B. H., Muller, C. L., Collins, A. L., Boyle, S. H., Kuhn, C. M., Siegler, I. C., Williams, R. B., and Ashley-Koch, A.
(2008) 5-HTTLPR and gender moderate changes in negative affect responses to tryptophan infusion. Behav. Genet. 38, 476-483.

(93) Walderhaug, E., Magnusson, A., Neumeister, A., Lappalainen, J., Lunde, H., Refsum, H., and Landro, N. I. (2007) Interactive effects of sex and 5-HTTLPR on mood and impulsivity during tryptophan depletion in healthy people. Biol. Psychiatry 62, 593-599.

(94) Dragan, W. L., and Oniszczenko, W. (2006) Association of a functional polymorphism in the serotonin transporter gene with personality traits in females in a Polish population. Neuropsychobiology $54,45-40$.

(95) Du, L., Bakish, D., and Hrdina, P. D. (2000) Gender differences in association between serotonin transporter gene polymorphism and personality traits. Psychiatr. Genet. 10, 159-164.

(96) Bale, T. L., and Epperson, C. N. (2015) Sex differences and stress across the lifespan. Nat. Neurosci. 18, 1413-1420.

(97) Olivier, J. D., Van Der Hart, M. G., Van Swelm, R. P., Dederen, P. J., Homberg, J. R., Cremers, T., Deen, P. M., Cuppen, E., Cools, A. R., and Ellenbroek, B. A. (2008) A study in male and female 5-HT transporter knockout rats: an animal model for anxiety and depression disorders. Neuroscience 152, 573-584.

(98) Carroll, J. C., Boyce-Rustay, J. M., Millstein, R., Yang, R., Wiedholz, L. M., Murphy, D. L., and Holmes, A. (2007) Effects of mild early life stress on abnormal emotion-related behaviors in 5HTT knockout mice. Behav. Genet. 37, 214-222.

(99) van den Hove, D. L., Jakob, S. B., Schraut, K. G., Kenis, G., Schmitt, A. G., Kneitz, S., Scholz, C. J., Wiescholleck, V., Ortega, G., Prickaerts, J., Steinbusch, H., and Lesch, K. P. (2011) Differential effects of prenatal stress in 5-Htt deficient mice: towards molecular mechanisms of gene $\mathrm{x}$ environment interactions. PLoS One 6, No. e22715.

(100) Ruijter, J. M., Ramakers, C., Hoogaars, W. M., Karlen, Y., Bakker, O., van den Hoff, M. J., and Moorman, A. F. (2009) Amplification efficiency: linking baseline and bias in the analysis of quantitative PCR data. Nucleic Acids Res. 37, No. e45. 